University of Leeds on the topic "Progress in the Chomistry and Technology of Pigments" which covered the physical chemistry of pigments. Dr Patterson has taken the proceedings of the school as a basis and with additional material has compiled the first available book on the topic. Normally summer school proceedings do not provide a sufficiently coherent body of information to make a readable book, but the policy of combining a chapter on some aspect of general theory with another on the application of the theory to pigment problems has avoided the dangers most effectively. The text still betrays its spoken origins. For example, there is the occasional "verbless sentence". This tends, however, to maintain a brisk informal style which carries the reader forward.

Five of the ten chapters are concerned with colour. Theories of colour of inorganic and organic molecules are considered in the first two chapters. In dealing with organic molecules very great emphasis is placed on the free electron method of calculating light absorption with perhaps too little attention paid to molecular orbital and valence bond methods. One chapter is concerned with the colour of organic crystals with interesting information about orientation effects on light absorption mechanisms. Two further chapters on colour are concerned with instrumental methods of colour measurement and colour match prediction, respectively. The particular aspects of pigments are considered in four chapters concerned with nucleation and growth of particles, particle size measurement, surface activity and theories of dispersion, flocculation and flotation. Photoexcitation in pigment crystals is considered in relation to the question of photoconduction and the degradation of organic molecules. This chapter is accommodated less easily than the others, but the editor's contention that photoconduction studies in this field are of special relevance to the question of the light fastness of pigments is woll supported.

This book succeeds in what it sets out to do, namely, to indicate in some detail the scope of a far ranging subject. It will prove of great value to students or research workers coming fresh to pigment problems, providing a guide to their further education.

I. D. RATtee

\section{REFERENCE TO PLUTONIUM}

\section{Plutonium Handbook}

A Guide to the Technology. Vol. 1. Edited by O. J. Wick. Pp. $x+520$. (New York and London: Gordon and Breach, 1967.) $\$ 26$.

THE aims of the two volumes of this work are stated as being the provision of information on a wide range of topies concerned in the utilization of plutonium and of a first reference on its technology. In view of the progressive relaxation of classification restrictions since the first limited relcase of information on the properties of plutonium in the United States and Britain in 1954, these objectives constitute a very considerable task. The editor is therefore to be congratulated on producing a first volume of manageable proportions which covers the physics, metallurgy and chemistry of the metal and its compounds. The sub-title of the work, "A Guide to the Technology", seems inappropriate for the first volume, although a preview of the chapter titles for the second volume suggests that it may be more applicable to the latter.

The individual chapters have been written by acknowlodged experts in the appropriate fields from a number of American atomic energy laboratories. Not unexpectedly, major contributions have been made by the Los Alamos and former Hanford, now Pacific North West, Laboratories. Clearly it has taken a considerable time to bring together all the individual contributions into a single volume and the most, recent references qunted are dated
1965. In particular, no reference is made to any of the papers presented at the Third International Conference on Plutonium held in London in November 1965. Some qualification must be made, therefore, about using the work as a first reference. Within individual chapters the authors have attempted to incorporate references to work throughout the world, though naturally there is a preponderance of American references in view of the large proportion of the work which has been done in that country. The chapter lengths are very uneven and a more balanced result might have been achieved if subjects of equal weight had been chosen for each chapter. Minor chapters such as "Metallography" and "Laboratory Techniques" might well have been combined or even omitted. There is also some overlap between different chapters which could have been cut out without great loss; for example, data on the $\mathrm{Pu}-\mathrm{O}$ and $\mathrm{Pu}-\mathrm{C}$ systems. The author index and subject index are only to be published with the second volume which provides a slight limitation on the value of the first volume alone. Having made these criticisms, however, it must be said that the principal chapters are in general excellent, both in technical content and in readability.

The book will undoubtedly find use in all plutonium laboratories as a compilation of the principal features of the chemistry and metallurgy of plutonium and its compounds, although the combined price of the two volumes is likely to be rather prohibitive for individual purchasers. P. G. MARDON

\section{TWENTY YEARS ON}

\section{Dynamic Aspects of Biochemistry}

By Ernest Baldwin. Fifth edition. Pp. xiv +466 . (London: Cambridge University Press, 1967.) 558. net; $\$ 9.50$.

IT says much for the original dynamism of Professor Baldwin's book that it reappears now in its fifth edition some twenty years after it first burst on the biochemical scene. The two previous editions had given the impres. sion that the book was beginning to lose ground a littlo in the rapid advance of the subject. It was to be hoped that this would be redressed in a new edition, which has been reset in a larger format and for which, it is claimed, a major revision has been made. It is a great disappoint. ment to have to report that these hopes are largely in vain. 'Two chapters, those on protein biosynthesis and fat metabolism, have indeed been completely rewritten and another, on special aspects of nitrogen metabolism, has been dismantled, but much remains which is now outdated. For example, it detracts much from the valuc of the book to read speculations concerning the position of the extra phosphate group in $\mathrm{NADP}^{+}$, or again those about the origin of deoxyribose, which take no account of Reicherd's work on reduction at nucleotide level. Even worse is the misstatement concerning the localization in the cell of the iso-citrate dehydrogenases and there are erroneous formulae such as those for active methionine and ubiquinone which have been transferred uncorrected from the fourth edition.

The chief criticism of the book, however, must be its failure to deal with important new developments in biochemistry. One could list such topics as isoenzymes, allosterism and the relationship between structure and function in enzymes as exemplified by ribonuclease and lysozyme.

The opportunity has been missed to revitalize Dynamic Aspects to meet the demanding requirements of the honours student who has, nowadays, a number of excellent modern texts available. To those, however, approaching biochemistry for the first time and for whom a complete and balanced up to date coverage is not a requirement, then Dynamic Aspects may well be recommended. C. A. Ross 